\title{
AVI S. LIFSCHITZ \\ Translation in theory and practice: the case of Johann David Michaelis's prize essay on language and opinions (1759)
}

Translators have traditionally been both inclined and well-placed to reflect about the attempt to convey in one language a sense moulded in another. Various eighteenth-century translations, from biblical versions to literary works, contain such reflections in the translator's preface, where dilemmas are explained and strategies justified. But these professional introductions were seldom rendered into other languages, even in translations at second hand, for translators faced unique problems in different target languages. A translation of reflections on language and translation must have been a challenging act, especially if its author was a polyglot specialist in philology and hermeneutics. This was, however, the task confronted by the translators of Johann David Michaelis's (1717-1791) treatise on the reciprocal influence of language and opinions. The essay, written in German and honoured in 1759 by the Berlin Academy with its annual prize, contained several references to the art of translation, further developed in other publications by Michaelis. The renowned Göttingen orientalist, whose main project was an original reinterpretation of the cultures of the ancient Near East, translated and annotated works composed in various languages - from English and French to Greek, Latin, Arabic, and Hebrew. Works by Michaelis were themselves translated into several European vernaculars, endowing him with what Umberto Eco recently called 'active and passive' experience in the field: both translating and being translated. ${ }^{1}$ The case of Michaelis's prize essay is particularly telling: not only was it rendered into other languages, but the process of translation differed substantially between French and English. From voluntary academic teamwork closely supervised by the author to a pirated second-hand transla-

* This article was written during a research sojourn at the Clark Library and the Center for Seventeenth- and Eighteenth-Century Studies at UCLA; I am grateful to the Center's director, Peter Reill, and his team for their hospitality.

1. Umberto Eco, Mouse or rat? Translation as negotiation (London 2003), p. 1-8. 
tion, the foreign editions of the essay may provide an insight into the theory and practice of translation in the eighteenth century. ${ }^{2}$

\section{Theory: language, opinions, and translation}

In 1757, the Berlin Academy announced the topic of its annual essay competition for 1759: the reciprocal influence of language on opinions and of opinions on language. ${ }^{3}$ This was the first of four contests the Academy dedicated in the second half of the eighteenth century to the philosophy of language and the comparison between European vernaculars (the most famous among them was arguably the 1771 competition on the origin of language, won by Johann Gottfried Herder). In 1757, two parallel philosophical strands led the class of speculative philosophy at the Academy (rather than its class of belles lettres) to choose the reciprocal influence of language and opinions as its prize topic. The first was the impact of French inquiries into the joint origins of society, language, and the human mind, as carried out by Etienne Bonnot de Condillac in his Essai sur l'origine des connoissances humaines (1746), in Denis Diderot's Lettre sur les aveugles and Lettre sur les sourds et muets $(1749,1751)$, and in Jean-Jacques Rousseau's Discours sur l'origine et les fondements de l'inégalité parmi les hommes (1754-1755). These were all conjectural histories of the emergence of higher mental operations alongside the arts and social institutions, in which the use of conventional signs was deemed indispensable for human mastery over the indistinguishable mass of sensations. Language was also seen as a prerequisite for the evolution of social ties, the development of the sciences, and the acquisition of a self-conscious historical perspective on the development of the individual and society as a whole.

2. The prize essay was also translated into Dutch as Prysverhandeling over den wederkeerigen invloed van de aangenoomen begrippen onder een volk op de nationaale taal, en van de taal op de nationaale wyze van denken, transl. by Cornelius van Engelen (Harlingen, Volkert van der Plaats junior, 1771). Unlike the cases detailed below, I have not found in Michaelis's Nachlaß any references to the translation itself or correspondence with the translator. This article is therefore limited to the French and English editions of the prize essay.

3. 'Quelle est l'influence réciproque des opinions du peuple sur le langage et du langage sur les opinions? [...] Après avoir rendu sensible comment un tour d'esprit produit une Langue, laquelle Langue donne ensuit à l'esprit un tour plus ou moins favorable aux idées vraies, on pourroit rechercher les moyens les plus pratiquables de remédier aux inconvéniens des Langues.' Carl Gustav Adolf von Harnack, Geschichte der Königlich Preußischen Akademie der Wissenschaften zu Berlin (Berlin 1900), II.306. 
Pierre Louis Moreau de Maupertuis, the French president of the Berlin Academy, had written in 1748 an essay titled Réflexions philosophiques sur l'origine des langues et la signification des mots, published for the first time in 1752; in 1756 he delivered at the Academy his Dissertation sur les différents moyens dont les hommes se sont servis pour exprimer leurs idées. ${ }^{4}$ Maupertuis roughly followed Condillac's account of the mutual emergence of language and the human mind, but Rousseau's Discours sur l'inégalité of 1755 problematised this line of argumentation. Rousseau presented his readers with two conundrums: language must have been indispensable for the establishment of society, while social ties were necessary for the use of conventional signs; and whereas signs were needed for the expression of general terms, such terms could not have emerged without language. Perplexed by these vicious circles, Rousseau doubted whether language could have emerged exclusively by human means. ${ }^{5}$ Rousseau's doubts were immediately appropriated by defenders of the divine origin of language, such as Johann Peter Süßmilch. Süßmilch, a pastor and pioneer of modern statistics who sought divine patterns in different sets of demographic data, publicly attacked Maupertuis in two papers he read at the Academy in $1756 .{ }^{6}$ At the same time, Rousseau's challenges were tackled by thinkers who espoused the naturalist account of the emergence of language and society, even if not in Condillac's vein. Gotthold Ephraim Lessing frequently discussed the matter with his friend Moses Mendelssohn, who addressed the issue of the origins of language in a postscript to his translation (1756) of Rousseau's Discours sur l'inégalité.

4. For the Dissertation, see Histoire de l'Académie royale des sciences et belles lettres, année 1754 (Berlin, Haude \& Spener, 1756), p. 349-364; the Réflexions is available in Sur l'origine du langage, ed. Ronald Grimsley (Geneva 1971), p. 27-46. On the debate between Maupertuis and Turgot on the origin of language, see Avi S. Lifschitz, 'Language as the key to the epistemological labyrinth: Turgot's changing view of human perception', Historiographia linguistica 31 (2004), p. 345-365.

5. 'Quant à moi, effrayé des difficultés qui se multiplient, et convaincu de l'impossibilité presque démontrée que les langues aient pu naître et s'établir par des moyens purement humains, je laisse à qui voudra l'entreprendre la discussion de ce difficile problème, lequel a été le plus nécessaire, de la société déjà liée, à l'institution des signes, ou des langues déjà inventées, à l'établissement de la société.' Jean-Jacques Rousseau, 'Discours sur l'origine et les fondements de l'inégalité parmi les hommes', in Discours sur l'origine et les fondements de l'inégalité parmi les hommes; Discours sur les sciences et les arts, ed. Jacques Roger (Paris 1992), p. 208-209.

6. Süßmilch's lectures were published a decade later as Versuch eines Beweises, daß die erste Sprache ihren Ursprung nicht vom Menschen, sondern allein vom Schöpfer erhalten habe (Berlin, Buchladen der Realschule, 1766). 
The second line of inquiry leading to the prize question on language and opinions was the contemporary fascination with the question of the 'genius of language' - the relations between the particular qualities of different languages and their speakers' cultural achievements. This time-honoured topos became especially poignant in Berlin of the $1750 \mathrm{~s}$, where a young generation of intellectuals was trying to apply the German language to relatively new literary forms (bourgeois drama and novels), while further developing Alexander Gottlieb Baumgarten's aesthetics to justify a break with neoclassical French standards. This endeavour was laden with problematic ramifications in a kingdom whose monarch was an avowed Francophile, where French was the official language of the local Academy, and whose intellectual life was substantially enriched by a large Huguenot colony and by visiting or asylum-seeking philosophes. A French member of the Academy, André Pierre le Guay de Prémontval, was particularly interested in the supposedly incommensurable differences between Latin, German, and French. Prémontval's lectures at the Academy merged with the wider debates over language and mind in France and Germany, leading the class of speculative philosophy to adopt his suggestion to conduct the 1759 prize contest on the reciprocal influence of language and opinions.

The 1759 competition was therefore largely modeled after what Hans Aarsleff termed 'the tradition of Condillac', essays on the mutual development of mind and language in the French manner. ${ }^{7}$ The crowned author was, however, a German orientalist of a Pietist and Wolffian background, who offered the Academy a treatise inspired to a large extent by Leibniz, Haller, Lowth, and the Baumgarten brothers (Alexander Gottlieb and his elder brother, the theologian Siegmund Jacob). ${ }^{8}$ What might have endeared Michaelis's essay to the Berlin jurors was his decisively naturalist account of the emergence of language. Michaelis had developed this perspective through a rejection of some of the ideas of earlier philologists and biblical scholars, in-

7. Hans Aarsleff, 'The Tradition of Condillac: the problem of the origin of language in the eighteenth century and the debate in the Berlin Academy before Herder', in From Locke to Saussure: essays on the study of language and intellectual history (London 1982), p. 146209.

8. For Siegmund Jacob Baumgarten's influence on the young Michaelis, see Johann David Michaelis, Lebensbeschreibung von ihm selbst abgefaßt, ed. Johann Matthäus Hassencamp (Leipzig, Johann Ambrosius Barth, 1793), p. 3-9. On Baumgarten, see Martin Schloemann, Siegmund Jacob Baumgarten: System und Geschichte in der Theologie des Übergangs zum Neuprotestantismus (Göttingen 1974) and David Sorkin, 'Reclaiming theology for the Enlightenment: the case of Siegmund Jacob Baumgarten (1706-1757)', Central European history 36 (2003), p. 503-530. 
cluding his own ancestors. ${ }^{9}$ Denying that Hebrew was the original language of mankind, Michaelis also ruled out any search for a language reflecting real essences. These convictions made him resort to naturalist arguments about the regular development of Hebrew and the natural emergence of language in general.

Michaelis's treatise stood out among other essays submitted for the contest, since most authors predictably tied the question of the reciprocal influence of language and mind to the contemporary debate over their origins. Michaelis acknowledged the close relationship between these two topics, but recommended that another contest be dedicated to the origin of language (his proposal bore striking similarity to the question eventually set for the 1771 contest). ${ }^{10}$ The prize essay included the popular notion of historical linguistics as a cognitive history of the human mind, but Michaelis did not limit his appreciation of language solely to its mental functions. He focused on a synchronic view of language as an ongoing project of a living community of speakers, an enterprise in constant flux. His principled objection to artificial scientific idioms and his espousal of the common use of the vernacular had strong republican overtones, which Michaelis did not conceal. Emphasising the link between science and literature (especially in the works of his Göttingen mentor Albrecht von Haller), Michaelis also proposed practical means for a cultural revival in German; in his prize essay, he applied French conjectural insights to domains hitherto external to the philosophical discussions of language.

Throughout the prize essay, Michaelis referred several times to the theory of translation and its practice in France and Germany. Having translated parts of Samuel Richardson's Clarissa into German in 1748, Michaelis knew the difficult choices faced by a translator. ${ }^{11}$ His call in the prize essay for the teaching of botany and other sciences in German might have stemmed not only from his experience as a translator, but also from a frustrating attempt to write in French. In 1758, Michaelis annotated a French treatise on the biblical

9. Johann David's father, Christian Benedict Michaelis (1680-1764), and his great uncle, Johann Heinrich Michaelis (1668-1738), were both biblical scholars and specialists in oriental languages at Halle.

10. 'En supposant les hommes abandonés à leurs facultés naturelles, sont-ils en état d'inventer le langage? Et par quels moyens parviendront-ils d'eux-mêmes à cette invention? On demanderoit une hypothèse qui expliquât la chose clairement, et qui satisfit à toutes les difficultés.' Harnack, Geschichte, II.307.

11. On Michaelis's translation of Clarissa, see Wilhelm Ruprecht, Väter und Söhne: zwei Jahrhunderte Buchhändler in einer Universitätsstadt (Göttingen 1935), p. 48-49; Thomas O. Beebee, Clarissa on the Continent: translation and seduction (University Park [PA] 1990). 
account of the crossing of the Red Sea, where he apologised for writing in a foreign language.

\begin{abstract}
J'en demande pardon aux lecteurs, particulièrement si faute de connoissance de la langue je n'ai pas pu donner à mes expressions toute la politesse que je devois à l'auteur. [...] Je sais bien quelle est la delicatesse du stile François, \& combien je dois paroitre à mon desavantage: mais je crois mon lecteur trop généreux, pour rire au dépens d'un homme, qui pour l'amour de la vérité publie ses remarques en mauvais François, \& fait des notes trop courtes pour le pouvoir ennuyer. ${ }^{12}$
\end{abstract}

Though never mentioning his personal experience in the prize essay, Michaelis emphasised the importance of translations and criticised German publishers for producing flawed versions of French and English books. Conforming to contemporary views, Michaelis saw most German translations as 'scholastic' while accusing French translators of taking excessive liberties with their source texts. ${ }^{13}$ Requiring translators to have an 'original spirit' in remoulding their source text, Michaelis also warned in his essay against domestication, a complete adaptation of the text to the conventions of the target language. One of the translator's most difficult dilemmas, Michaelis noted, was how to convey the accessory ideas accompanying words alongside their principal meanings. Here Michaelis placed a premium on the source language, recommending a somewhat forceful mutation of the host medium.

Les bonnes traductions corrigent souvent ce défaut de la langue en hazardant d'attacher aux mots de nouvelles significations, auxquelles le lecteur s'accoutume peu à peu. Il est vrai que dans les commencemens la traduction paroîtra obscure \& peu fidèle dans ces endroits; c'est un inconvénient inévitable; mais qui est racheté par un plus grand bien. ${ }^{14}$

Michaelis's tendency to challenge the reader by endowing translations with seemingly strange and foreign-sounding expressions became a hallmark of his later theory of translation, particularly in his version of the Old Testament. In the introduction to the first volume of this project (the Book of Job, 1769), Michaelis seemed to adopt the common early modern method of trans-

12. Editor's preface in Pierre Hardy, Essai physique sur l'heure des marées dans la mer rouge, comparée avec l'heure du passage des hébreux, ed. Johann David Michaelis (Göttingen, Pockwitz \& Barmeier, 1758), p. 3.

13. '[...] Il faudroit qu'elles [les traductions] fussent \& moins scholastiques que celles que nous voyons paroitre en Allemagne, \& plus fideles que celles que la France produit.' Johann David Michaelis, De l'influence des opinions sur le langage et du langage sur les opinions, transl. by Jean Bernard Merian and André Pierre le Guay de Prémontval (Bremen, George Louis Förster, 1762), p. 153. I am using the extended and authorised French version of the prize essay; for its history, see below.

14. Michaelis, De l'influence, p. 99. 
lating 'sense for sense' rather than 'word for word', denouncing literal translation as 'slavish'. ${ }^{15}$ But his preference for the source text was manifest in his comparison of the 'germanisation' of oriental poetry to a bust of Cicero clad in the latest eighteenth-century fashion. ${ }^{16}$ It would be ridiculous, Michaelis claimed, to purge biblical poetry of its distinctive features for the sake of clear and explanatory prose. The original style should appear through the cloak of translation, and if this required an effort on the readers' part, they simply had to endure the challenge. Michaelis admitted that readers' pleasure was not his first priority.

Es müßte nicht mein Stilus seyn, sondern der Stilus des Concipienten, oder der müßte doch einiger maßen durchscheinen, sonst würde es jedem vernünftigen Leser Verdacht erwecken: selbst wenn einer, um eine Probe von Geschmack der Orientalischen Dichtkunst zu haben ein Arabisches Gedicht übersetzt verlangte, würde ich es nicht zum deutschen Original machen, denn sonst wäre ja sein ganzer Zweck vereitelt. ${ }^{17}$

Retaining the oriental features of the text, or making modern German sound like ancient poetry, was not too difficult a task in Michaelis's eyes. He saw several affinities between contemporary German and biblical Hebrew. German - like English - paralleled Hebrew in its original turns of phrase, boldness of expression, and freedom of usage, whereas French suffered under artificial rules and over-sensitivity to social norms: Haller and Klopstock knew how to 'poetise orientally' ('orientalisch dichten') in German. ${ }^{18}$

Michaelis's introductions to his biblical translations re-emphasised his inclination, already evident in the 1759 prize essay, to prefer the method of foreignising a translated text to familiarising or simplifying it. The additional effort required of the readers would alert them to the unique traits of the source text and its cultural contexts. This aversion to over-familiarisation and in-

15. On the paradigms of early modern translation, see Fania Oz-Salzberger, 'Translation', in Encyclopedia of the Enlightenment, ed. Alan Charles Kors (Oxford 2003), IV.181-188; Lawrence Venuti, 'Introduction', in The Translation studies reader (London 2000), p. 11-20.

16. Johann David Michaelis, 'Vorrede der ersten Ausgabe' (1769), in Deutsche Uebersetzung des Alten Testaments, mit Anmerkungen für Ungelehrte. Der erste Theil, welcher das Buch Hiobs enthält (Göttingen and Gotha, Johann Christian Dieterich, 1773), p. xix-xxi. On Michaelis's translation of the Old Testament, see Jonathan Sheehan, The Enlightenment Bible: translation, scholarship, culture (Princeton 2005), p. 182-220.

17. 'It should not be my style, but the style of the conceiver; or his style should anyhow be discernible through the text - otherwise it would raise suspicion in any reasonable reader. Even if I were asked to translate an Arabic poem in order to sample the art of oriental poetry, I would not have turned it into a German original, for this would have missed the whole point.' Michaelis, 'Vorrede zur zweiten Ausgabe', Deutsche Uebersetzung, p. lvii. Unless otherwise noted, all translations are by the author.

18. Michaelis, Deutsche Uebersetzung, p. Iviii-lx. 
sistence on a critical distance overshadowed Michaelis's more conforming gestures towards a middle way between 'slavish loyalty' and 'germanisation' in translation. For Michaelis, the translator's originality consisted in conveying in German the foreignness of the source, not in making it sound as if it had initially been a German composition. ${ }^{19}$ This notion was accompanied in Michaelis's works with a qualitative assessment of European vernaculars. In this scheme, the budding literary idiom of Germany resembled biblical Hebrew, both languages as yet unencumbered by formal rules and stifling norms of usage.

\section{Praxis: translations into French and English}

The widespread fascination with Michaelis's theoretical perspective was demonstrated by the heated debate his prize essay stimulated. The perpetual secretary of the Berlin Academy, Jean Henri Samuel Formey, responded by admitting no speculations, only facts concerning the relations between language and mind; Moses Mendelssohn and Johann Georg Hamann argued that man was too immersed in language to inquire into its origins and mental functions. Herder, who shared Michaelis's general aim of a cultural revival in the vernacular, inconsistently criticised the prize essay for being both too general and minutely detailed. ${ }^{20}$ Prémontval took up Michaelis's endorsement of German in a vehement attack on what he called Gallicomanie, the excessive vogue in Berlin for anything Parisian, which allegedly corrupted the local French dialect while thwarting the attempts to cultivate German literature. ${ }^{21}$

19. This tendency may be perceived in most of Michealis's scientific projects of the 1750 s and 1760 s, especially in his instructions to the experts sent by the Danish king to explore the Arabian peninsula: Johann David Michaelis, Fragen an eine Gesellschaft gelehrter Männer, die auf Befehl Ihro Majestät des Königes von Dännemark nach Arabien reisen (Frankfurt/Main, Johann Gottlieb Garbe, 1762).

20. Jean Henri Samuel Formey, 'Réunion des principaux moyens employés pour découvrir l'origine du langage, des idées \& des connoissances des hommes', Histoire de l'Académie royale des sciences et belles lettres, année 1759 (Berlin, Haude \& Spener, 1766), p. 367-377; Moses Mendelssohn, Gesammelte Schriften - Jubiläumsausgabe, ed. Eva J. Engel (StuttgartBad Cannstatt 1991), vol. V.1, p. 105-118; Johann Gottfried Herder, 'Über die neuere deutsche Literatur - Fragmente', in Frühe Schriften 1764-1772, ed. Ulrich Gaier (Frankfurt/Main 1985), p. 563-564.

21. Prémontval's campaign against the Huguenots' language was carried out in his periodical Préservatif contre la Corruption de la Langue Françoise, en France, \& dans les Pays où elle est le plus en usage, tels que l'Allemagne, la Suisse, \& la Hollande (Berlin, Georg Ludwig Winter and Grynäus \& Decker, 1759-1761). On the lengthy affair caused by this publication, see Avi S. Lifschitz, 'From the corruption of French to the cultural distinctiveness of 
But as the lively debate over language and mind was reinvigorated and further problematised by Michaelis's prize essay, many readers in Berlin including French members of the Academy - had access only to a short French abstract of the essay, printed with the German prize essay in 1760. Michaelis was thus only too glad to cooperate with Prémontval and Jean-Bernard Merian, the Academy's deputy secretary, when they suggested undertaking a full French translation.

Having maintained close contact with Prémontval since the early 1750s, Michaelis trusted his Berlin correspondent, who was to revise Merian's translation. Merian soon learned that Michaelis believed translation not only required an effort on the reader's part, but also much trouble on the translator's behalf. From 1759 until 1762 Michaelis and Merian frequently exchanged drafts, revisions, and proofs, testifying to a remarkable level of collaboration between an author and his translator. Michaelis, wishing to remain in control of the end-product, addressed Merian with various remarks and requests, always doubting whether his translators had conveyed the precise sense of his arguments. Versed in oriental, classical, and modern European languages, Michaelis was well aware of idiomatic peculiarities. But he had such a difficulty in acquiescing to the translators' changes that Merian repeatedly had to remind him of the stylistic differences between German and French. 'Pour faire goûter votre livre en françois, il faut l'accommoder au génie de cette langue', Merian wrote to Michaelis in late 1759, to no avail. In the next year Merian found himself explaining again to Michaelis the predicament of a translator from German into French, apologising for the idiosyncrasies of the target language.

Vous verres, Monsieur, que nous nous sommes conformés à vos idées par-tout où le génie de la langue françoise l'a permis. Cette langue est une grande gêne pour un traducteur. [...] Ce fréquent usage des particules, toutes les superfluités, le trop de développement, les périodes trop allongées par des propositions incidentes, et le manque d'harmonie sur-tout sont des défauts insupportables dans cette Langue, et capable de décrier les ouvrages les plus excellens pour le fonds. ${ }^{22}$

German: the controversy over Prémontval's Préservatif', in Enlightenment and tradition: women's studies; Montesquieu, ed. Jonathan Mallinson et al. (Oxford 2007), p. 265-290.

22. Undated letter (sent in 1760), Göttingen, Niedersächsische Staats- und Universitätsbibliothek, Codex Michaelis 324, p. 51r-v. The translation of the prize essay so exhausted Merian, that he made further collaboration with Michaelis conditional on higher remuneration and the employment of a copyist: Merian to Michaelis, 17 Nov 1761, Codex Michaelis 324, p. 68r-69r. 
The arduous work and difficult interaction finally justified the efforts on both sides. Michaelis extended the original essay with several appendices, Merian proved a submissive though astute translator, and Prémontval took care of some stylistic revisions. In his autobiography Michaelis noted that the prize essay would not have been a landmark in his career, were it not for the excellent French translation by Merian and Prémontval. ${ }^{23}$ The French edition was selectively distributed in Paris by Michaelis's friend Thierry, regent of the local faculty of medicine, who expressed his admiration for the new views introduced by Michaelis to the language debate and demanded more copies for local scholars. ${ }^{24}$ One of the copies reached Jean le Rond d'Alembert, who consulted Frederick II frequently on academic matters following Maupertuis's death (1759). As part of the king's attempts to reinvigorate the Academy after the Seven Years War, d'Alembert was invited to spend summer 1763 in Berlin, where he attended several meetings of the Academy. ${ }^{25}$ Following d'Alembert's enthusiastic response to the French version of the prize essay, Michaelis was offered a well-salaried post in Berlin.

Denn weil er [d'Alembert] das Französische der Preißschrift sur l'influence du langage für mein eigenes ansah, hielt er mich für einen sehr guten französischen Schriftsteller, und machte mir, als ich in einem französischen Briefe wegen meiner Schreibart um Vergebung bat, dieß unverdiente Compliment: die schönen Geister in Paris würden sehr vergnügt seyn, wenn sie so gut französisch schreiben könnten, wie die Schrift sur l'influence geschrieben wäre. $^{26}$

Michaelis corrected d'Alembert's mistake, paying Merian and Prémontval their due, but this comedy of errors shed some light on the mechanism of aca-

23. Michaelis, Lebensbeschreibung, p. 57-58.

24. 'Je ne puis même vous cacher que si vous maniéz notre Langue avec tant de facilité, de force et d'elegance, il vous seroit peut-etre preferable de lui donner la preference dans la pluspart de vos ouvrages qui ne seront pas destines a votre Academie. J'ai fait lire votre dissertat. a 5 ou 6 de nos savans de l'Acad. des Inscriptions. Ils m'ont tous temoigné en etre fort satisfaits. Elle court actuellement de mains en mains, et je compte aussi la faire lire a nos gens du monde.' Thierry to Michaelis, 12 May 1762, Codex Michaelis 329, p. 273r-v.

25. Harnack, Geschichte, vol. I.1, p. 354-363; Eduard Winter, Die Registres der Berliner Akademie der Wissenschaften 1746-1766: Dokumente für das Wirken Leonhard Eulers in Berlin (Berlin 1957), p. 70-74 and p. 288.

26. 'Because d'Alembert assumed the French of the prize essay was my own, he took me for a very good French author. When I apologised for my style in a French letter, he made the following compliment: the bels esprits in Paris would have liked to write in such good French as that of the essay Sur l'influence.' Michaelis, Lebensbeschreibung, p. 59. Michaelis declined the offer from Berlin due to his gratefulness to the Hanoverian authorities, but in the 1770 s he felt that his loyalty had not been rewarded and tried to regain Frederick II's favour through d'Alembert. 
demic appointments in Berlin. The Prussian king was apparently willing to acquire only a German scholar recommended by a Parisian philosophe on the basis of his elegant French.

In stark contrast to the good fortunes of the French translation, the English version of the prize essay conformed to the norms of the eighteenth-century book market. It was a pirated translation at second hand, made anonymously from the French edition. Michaelis, who had been a freelance translator, should not have been surprised: contemporary publishers-booksellers (libraires) usually wished to maximise profits by abridging and mutilating the original text in various ways. Outside England, where the Statute of Anne (1710) partially protected the rights of authors and publishers, piracy was the rule rather than the exception - especially concerning translations. In most cases there was no contact whatsoever between authors and their translators (with a few notable exceptions, such as Edward Young and Johann Arnold Ebert). ${ }^{27}$ Michaelis, however, had a different experience of translating and being translated. His early translation of Clarissa notwithstanding, he fostered close relationships with the authors he translated or edited.

The fruitful exchange with his voluntary French translators was mirrored in Michaelis's correspondence as an editor with Robert Lowth, professor of poetry at Oxford and later Bishop of Oxford and London, whose Lectures on Hebrew Poetry he published in Göttingen. ${ }^{28}$ A similar liaison emerged between Michaelis and one of the readers of his edition of Lowth's Lectures, Robert Wood. Lowth and Michaelis considerably inspired Wood's accounts of his archaeological travels to Greece and the Near East in the 1750s, in which he stressed the significance of environmental and cultural background for the proper understanding of classical poetry. ${ }^{29}$ Having read Michaelis's annotations and his instructions to the Arabian expedition, Wood sent to Göttingen in 1769 one of the seven pre-printed copies of his Essay on the Original Genius and Writings of Homer. The Essay was enthusiastically received in Michaelis's circle, praised by Christian Gottlob Heyne in the Göttingische Anzeigen, and translated into German by Michaelis's nineteen year-old son, Christian Friedrich, even before its publication in English. ${ }^{30}$ The close link

27. Robert Darnton, 'The Science of piracy: a crucial ingredient in eighteenth-century publishing', in History of the book; translation; history of ideas; Paul et Virginie; varia, ed. Robert Darnton et al. (Oxford 2003), p. 3-29.

28. Robert Lowth, De sacra poesi Hebraeorum praelectiones academicae Oxonii habitae, ed. Johann David Michaelis, 2 vols (Göttingen, Pockwiz \& Barmeier, 1758 and 1761).

29. Robert Wood, The Ruins of Palmyra, otherwise Tedmor in the Desert (London 1753) and The Ruins of Balbec, otherwise Heliopolis in Coelosyria (London 1757).

30. Wood died in 1771; his Essay was posthumously published in England in 1775. The German edition is Robert Woods Versuch über das Originalgenie des Homers (Frankfurt/Main, An- 
with British orientalists, first forged by Michaelis in his English sojourn of 1741-1742, proved long-lasting and fruitful both in Germany and in Britain.

It was thus evidently disturbing for Michaelis to discover the pirated translation of his prize essay, published in London by Owen and Bingley in $1769 .{ }^{31}$ This edition included an English version of the French translators' preface, where Merian and Prémontval praised their collaboration with the author and assured the readers that all changes had been made with Michaelis's full consent. The Critical Review, quoting this preface, announced to the British audience that ' $\mathrm{t}]$ he translation, which is now presented to the public, was revised by Mr. Michaelis himself' ${ }^{32}$ The enraged Michaelis immediately saw himself obliged to disavow the pirated version publicly. Robert Lowth, influential and well-connected in the political and intellectual scenes, became the natural address for Michaelis's grievances. Lowth acted quickly, placing a letter in the Critical Review of January 1770 as an attempt to denounce the publication. The anonymous letter (signed by '**') strongly argued that the pirated translation deceived the public and did injustice to the author, who - according to the translated French preface - supposedly approved all the inaccuracies and grave mistakes the English edition contained. Lowth presented his letter as relating the complaints of 'a learned foreigner (than whom no one can be supposed to be a better judge in this matter, or to enter more readily and intimately into the meaning of the author)'; he further explained that the French translation had indeed been closely supervised by Michaelis, who, however, never communicated with any English translator. This renunciation might have sufficed as a public disavowal, but Michaelis asked Lowth to describe in detail how the authorised translation had been carried out.

The French language differs very greatly from the idiom of the German: and not only so, but it is tied up to such strict rules, it has so many niceties and delicacies, with regard to the turn of the expression, and the form of the period, that it is extremely difficult, if not impossible, to give a very close, and at the same time an elegant translation, from almost any language into French. [...] They [the translators] were therefore obliged to take considerable liberties

dreäische Buchhandlung, 1773). See Hans Hecht, 'Robert Wood und J. D. Michaelis', in T. Percy, R. Wood und J. D. Michaelis: ein Beitrag zur Literaturgeschichte der Genieperiode (Stuttgart 1933), p. 19-31.

31. Johann David Michaelis, A Dissertation on the Influence of Opinions on Language and of Language on Opinions, which Gained the Prussian Royal Academy's Prize on that Subject (London, W. Owen and W. Bingley, 1769).

32. The Critical Review, July 1769, p. 60. 
with the original, in regard to the expression and composition, in order to make the discourse appear graceful and agreeable in their own language. ${ }^{33}$

Michaelis's contemporary critique of the French language may be readily identified in Lowth's letter to the editors of the Critical Review. Lowth ended, at Michaelis's request, with a philosophical defence of direct translation and an explanation why the pirated version truly violated the original text.

A close translation, made at second hand from a free one, must carry with it a strong tincture of the medium through which it has passed; at the same time that it has no chance of recovering any thing that may have been lost of the native and genuine colour of the first composition: in this case especially, where the French language, equally discordant from the German and the English, stands in the way between both, and intercepts the natural communication of those two sister languages; which would have run immediately one into the other, with great facility and exactness, and with very little alteration of the form, or diminution of the spirit, of the original. ${ }^{34}$

Michaelis presented in this letter, through Lowth's agency, a noteworthy hypothesis: historically related languages (such as English and German) allowed for a literal or plain translation, whereas those pertaining to different families (Germanic and Romance) required a much freer rendition, closer to a paraphrase. Michaelis/Lowth did not further elucidate this argument, which apparently considered neither the large portion of English vocabulary influenced by Latin, Norman, and French nor the syntactic and lexical differences between English and German. Rather than documenting linguistic realities, the emphasis on a 'natural communication' of German and English and their alleged tendency to 'run immediately one into the other' in the face of a 'discordant' French seems to have reflected the intellectual climate in Germany of the time.

From a marginal idiom at the beginning of the eighteenth century, in the second half of the century English rose to prominence as a source language in the German book market, sometimes overtaking French (as in the cases of

33. The Critical Review, January 1770, p. 79-80. Lowth reported back to Michaelis about this letter: 'I found it would be of little purpose to make known your just complaint in a private way; \& to spread it as occasion should offer, through the small circle of my acquaintance. The case seemed to me to require that it should be laid in some proper manner before the public. [...] I have studiously inserted such particular circumstances from your Letter, as will easily induce the intelligent reader to believe that the Anonymous Letter-Writer speaks from the best authority.' Lowth to Michaelis, 3 Feb 1770, Codex Michaelis 325, p. 402r$403 r$.

34. The Critical Review, January 1770 , p. 80. 
imaginative literature and aesthetic theory). ${ }^{35}$ The deliberate circumnavigating of France and the French language was expressed not only in Michaelis's intellectual trajectory and his close alliance with British scholars. Contemporary works by some of Michaelis's correspondents (Mendelssohn, Lessing, Prémontval) expressed the similar conviction that a German cultural revival would be possible only through divorcing French influence - at the courts, in science, as aesthetic criteria - and by searching for alternative models such as Johann Joachim Winckelmann's ancient Greece, Johann Gottfried Herder's Shakespeare, or the aesthetics of Edmund Burke and Thomas Young.

\section{Conclusion}

The turn of the nineteenth century has traditionally been identified as a watershed in the transition towards a modern notion of translation. Friedrich Schleiermacher's call to 'leave the author in peace' and his source-oriented approach have particularly been singled out as a departure from the allegedly erratic eighteenth-century practice of paraphrasing, abridging, and domesticating texts in translation. ${ }^{36}$ This view coincided with Michel Foucault's identification of an epistemic shift around 1800 from the viewpoints of the âge classique to modern conceptions of language, nature, and society. ${ }^{37}$ However, like many other Enlightenment ideas, Johann David Michaelis's theory of translation undermines such a dichotomous distinction between the early modern and the modern outlooks, as do his attempts to implement his principles in practice.

The 1759 prize essay on the reciprocal influence of language and opinions further demonstrates that a synchronic view of language as a changing product of a living community, coupled with an acute awareness of historical change, was not an exclusively nineteenth-century view. Just as the origins of Historicism may be traced deep within the eighteenth century, the sources of the Romantic method of translation should be sought among Enlightenment thinkers. ${ }^{38}$ Michaelis's criticism of French linguistic domination or French

35. Fania Oz-Salzberger, 'The Enlightenment in translation: regional and European aspects', European review of history 13.3 (2006), p. 385-409 (p. 397-398).

36. See, most recently, Peter Burke, 'Cultures of translation in early modern Europe', in Cultural translation in early modern Europe, ed. Peter Burke and R. Po-Chia Hsia (Cambridge 2007), p. 7-38 (p. 35). For the famous statement, see Friedrich Schleiermacher, 'On the different methods of translating', transl. by Susan Bernofsky, in The Translation studies reader, ed. Lawrence Venuti (London 2000), p. 43-63.

37. Michel Foucault, Les mots et les choses: archéologie des sciences humaines (Paris 1966).

38. Peter H. Reill, The German Enlightenment and the rise of Historicism (Berkeley 1975). 
mediation between German and English was not a rejection of Enlightenment values: like similar comments by Diderot and Herder, it was part and parcel of the Enlightenment's positive appraisal of diversity and change in human affairs. The prize essay exemplified Michaelis's project in many of his subsequent works: the creation of a critical distance between travellers and explored regions, historians and past cultures, readers and translated texts, or more generally between interpreters and the language in which they are inevitably immersed. The different translations of the essay proved that while attempts could be made to realise such a vision, it remained a rare practice in a publishing industry governed by economic concerns. 